Journal of Bangladesh Chemical Society, Vol. 24(2), 215-220, 2011

DOI: 10.3329/jbcs.v24i2.9711

\title{
STUDIES ON THE PHYSICO-CHEMICAL PROPERTIES AND FATTY ACID COMPOSITION OF NYCTANTHES ARBOR-TRISTIS LINN LEAVES
}

\author{
MOHAMMAD MIZANUR RAHMAN ${ }^{1 *}$, SUDHANGSHU KUMAR ROY ${ }^{2}$ AND MOHAMMAD \\ SHAHJAHAN ${ }^{1}$ \\ ${ }^{I}$ Department of Chemistry, Government Jagannath College (present name: Jagannath University), \\ Dhaka-1100, Bangladesh. ${ }^{2}$ Chemical Research Division, BCSIR, Laboratories, Qudrat-i-Khuda \\ road, Dhaka-1205, Bangladesh.
}

\begin{abstract}
Seven fatty acids were isolated from pet-ether extract of Nyctanthes arbor-tristis Linn (Seuli) leaves. The relative percentages of the major fatty acids were identified by GLC as palmitic acid (23.88\%), linoleic acid (8.95\%), stearic acid (47.56\%) and oleic acid $(5.07 \%)$. The yield of the leaves fat was $2.10 \%$. Acid value of seed oil was found to be 76.27 and suggests that this oil is inedible. Physico-chemical characteristic, such as acid value, iodine value, moisture, ash, lignin, crude fibre, fat, protein and carbohydrate of the Seuli leaf were also determined.
\end{abstract}

Keywords: Seuli leaves, Nyctanthes arbor-tristis Linn, fatty acids composition.

\section{Introduction}

Bangladesh is flourished with plants, herbs and trees. Various plants are being used for medicinal purposes in Bangladesh and also in other parts of the Indian subcontinent. On the basis of the uses of these plants various traditional systems of medicine have been developed in this part of the world. In Ayurvedic and Unani system of medicine, decoction of the leaves of Nyctanthes arbor-tristis Linn is used in the treatment of sciatica, chronic fever, rheumatism, intestinal worms, laxative, cholagogue, diuretic, diaphoretic, expectorant and antimoebic purposes ${ }^{1,2}$.

Nyctanthes arbor-tristis Linn, a large shrub cultivated as a garden plant throughout Bangladesh is also found in sub-Himalayan region. Its Bengali name is Seuli. It is a $\mathrm{C}_{3}$ plant $^{3}$. It has highly fragrant flowers, white and yellow, which do not expand till evening and these flowers fall off before sunrise. Thus during the day the tree loses all its brightness and hence is called "The Sad Tree" (Arbor-Tristis). "Nyctanthes" means "Night-flowering". Present work mainly deals with the determination of physicochemical characteristics and analysis of fatty acids in Seuli leaves.

\section{Experimental}

The matured leaves of Seuli plants were collected from the Mymensingh region, Bangladesh during the month of November, 2002. The collected leaves were cleaned, dried and crushed mechanically. Leaves were powdered with machine and dried at $50^{\circ} \mathrm{C}$ for 3 hours.

*Corresponding author e-mail: pmizan@gmail.com 


\section{Physico-chemical studies}

Physico-chemical characteristics viz. colour, acid value, iodine value, moisture, ash, lignin, crude fibre, fat, protein and carbohydrate of Seuli leaves were determined as per standard method ${ }^{4-7}$ and the results are shown in Table 1.

\section{Extraction of leaves fat}

Solvent extraction method was employed for the extraction of fat from Seuli leaf. Dried powdered samples $(150 \mathrm{~g})$ were extracted with low boiling petroleum ether $\left(40^{\circ}-60^{\circ} \mathrm{C}\right.$ bp) in a Soxhlet extractor (18 hours). The petroleum ether was removed in a Rotary Vacuum Evaporator (Buchii, Switzerland) at $40^{\circ}-50^{\circ} \mathrm{C}$. The extract was dried in desiccators over silica gel and finally the fat sample was kept in a nitrogen atmosphere in a refrigerator.

\section{Preparation of leaves fatty acid methyl ester}

The esterification of the fat was carried out with $\mathrm{BF}_{3}-\mathrm{MeOH}$ complex ${ }^{8} .5 \mathrm{mg}$ of fat was taken in a reaction tube and $\mathrm{BF}_{3}-\mathrm{CH}_{3} \mathrm{OH}$ reagent $(5 \mathrm{~mL})$ was added and was boiled for 5 min. Hexane $(5 \mathrm{~mL})$ was added to it and boiled for further $1 \mathrm{~min}$. After cooling the tube, a saturated salt solution was added and vortexed. Then the upper layer containing methyl esters was transferred to a vial with anhydrous sodium sulfate at the bottom. Then the ester was filtered through syringe filter and transferred to a small vial $(2 \mathrm{~mL})$. The residual solvent was recovered by blowing nitrogen gas and stored in a refrigerator before analysis by GLC.

\section{Preparation of Standard fatty acid methyl ester (FAME)}

Standard fatty acid methyl esters (LIPID STANDARD; Sigma) of caprylic acid, nonanoic acid, capric acid, undecanoic acid, lauric acid, myristic acid, palmitic acid, linoleic acid, oleic acid, stearic acid, arachidic acid and behenic acids were used (Fig.1) for the identification of the sample peaks.

The compositions of the fatty acids were identified by comparing their retention time. The peak areas were calculated by multiplying the height of the peak with the width at half height (area $=$ height $\times$ width at half height). Relative percentage of the fatty acids were determined (Fig. 2) by comparing their peak areas and the fatty acid contents of Seuli leaves samples are given in Table 2. 


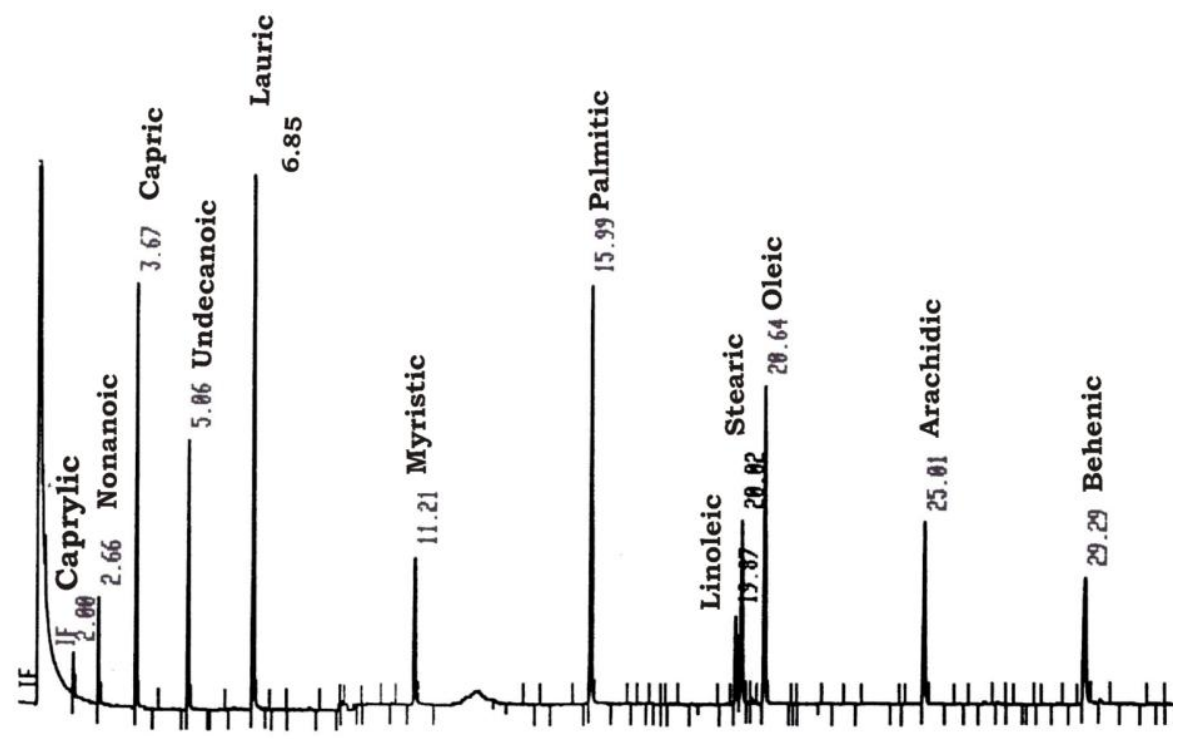

Fig. 1. Standard fatty acid methyl esters chromatogram analyzed by GLC.

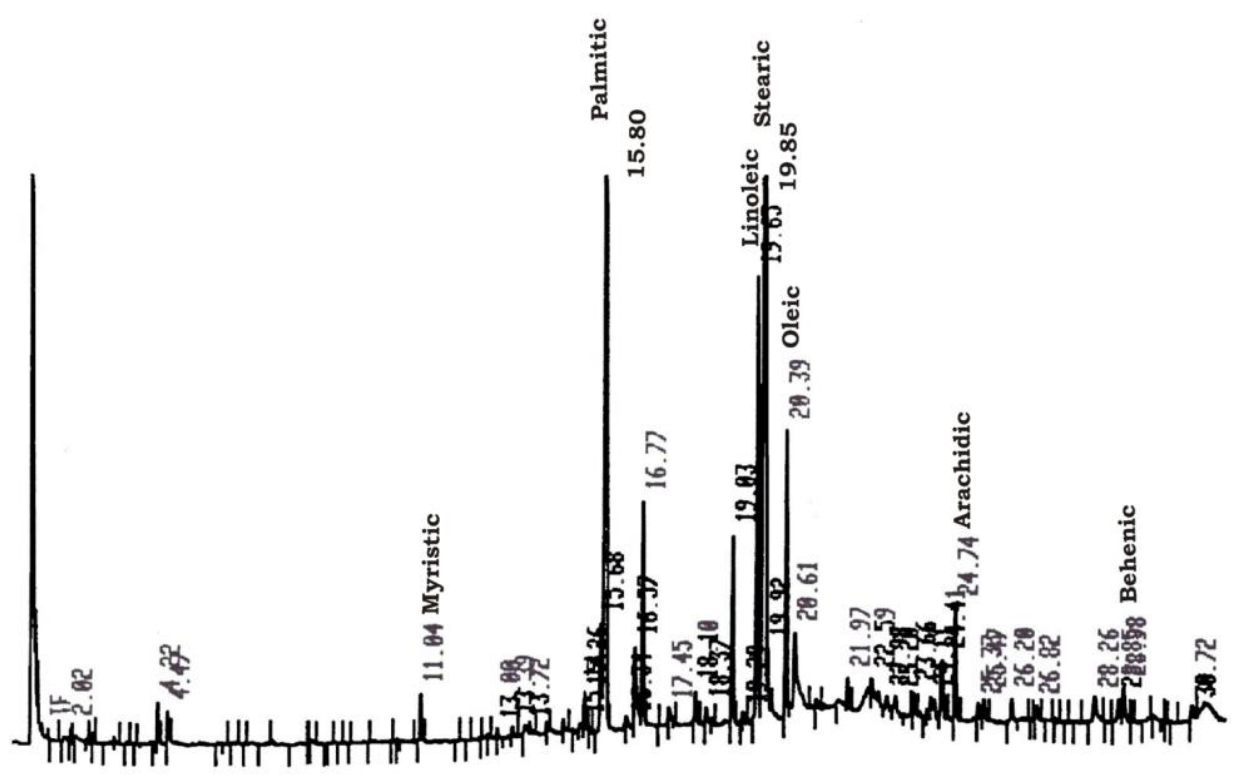

Fig. 2. Chromatogram of methyl ester of Seuli leaves fatty acid analyzed by GLC. 


\section{Gas Liquid Chromatography (GLC)}

The methyl esters of fatty acid were quantified by gas-liquid chromatography method using a capillary column $(2000 \mathrm{~mm} \times 4 \mathrm{~mm})$ equipped with a flame ionization detector (Pye Unicam 4500). Column packing was done with $10 \%$ diethylene glycol succinate on 100-120 mesh diatomic CAW with column temperature $100^{\circ} \mathrm{C}$, detector temperature $220^{\circ} \mathrm{C}$, hydrogen flow rate $4 \mathrm{~mL} / \mathrm{min}$ and samples volume of injected $0.1 \mathrm{~mL}$ was used.

\section{Results and Discussion}

Physico-chemical characteristics (Table 1) of Seuli leaves fat was determined to be $2.10 \%$. The fat was of dark green colour. It is a viscous semi solid substance at room temperature. Acid value of Seuli leaf fat was found to be 76.27. High acid value indicates that this oil is inedible. The iodine values of Seuli leaves fat were found to be 134.44. The result indicates that Seuli leaves fat is highly unsaturated.

Table 1. Physico-chemical characteristics of Nyctanthes arbor-tristis Linn leaves.

\begin{tabular}{lc}
\hline Characteristics of leaf fat & Result \\
\hline Colour & Dark green \\
Appearance & Viscous semi solid substance \\
Moisture & $50.01 \%$ \\
Ash & $13.98 \%$ \\
Lignin & $15.87 \%$ \\
Crude fibre & $9.41 \%$ \\
Fat & $2.10 \%$ \\
Protein & $15.02 \%$ \\
Carbohydrate & $9.48 \%$ \\
Acid value & 76.27 \\
Iodine value (Hanus method) & 134.44 \\
\hline
\end{tabular}

The Seuli leaf contained (Table 1) moisture 50.01\%, ash $13.98 \%$, lignin $15.87 \%$, crude fibre $9.41 \%$, fat $2.10 \%$, protein $15.02 \%$ and carbohydrate $9.48 \%$. Whereas $\mathrm{Singh}^{9}$ reported the ash and protein content $11.0 \%$ and $16.20 \%$ respectively, which were comparable to the value determined by us. 
The FAME compositions of Seuli leaves fat were determined by Gas Liquid Chromatograph (GLC). The relative percentages of the individual acids were found to be (Table 2) myristic acid $0.7 \%$, palmitic acid $23.88 \%$, linoleic acid $8.95 \%$, oleic acid $5.07 \%$, stearic acid $47.56 \%$, arachidic acid $2.14 \%$ and behenic acid $0.87 \%$. There are three unidentified peaks in the chromatogram, where the retention times were $16.77(\mathrm{~min})$, 19.03( $\mathrm{min}), 20.61(\mathrm{~min})$ and with relative percentages of $3.83,3.21$ and 3.72 respectively. It is evident from Table 2 that the percentages of stearic acid and palmitic acid were highest and the fat therefore may be tapped as a source of stearic acid and palmitic acid. Myristic and behenic acids were present in small amounts in the extract. Unsaturated fatty acids viz. oleic and linoleic acids were found to be moderate quantity.

\section{Conclusion}

The Seuli leaves fat is non edible oil. The main component of stearic acid was found to be higher percentage in the leaf fat. We recommended that the oil will use the industrial purposed.

Table 2. Fatty acids methyl ester composition of Nyctanthes arbor-tristis Linn leaf extract.

\begin{tabular}{lccc}
\hline Name of the acids & $\begin{array}{c}\text { Retention time } \\
(\mathrm{min})\end{array}$ & Area $(\mathrm{mm})$ & Relative \% \\
\hline Myristic acid & 11.04 & 1932 & 0.77 \\
Palmitic acid & 15.80 & 59564 & 23.88 \\
Linoleic acid & 19.65 & 22335 & 8.95 \\
Stearic acid & 19.85 & 118620 & 47.56 \\
Oleic acid & 20.39 & 12634 & 5.07 \\
Arachidic acid & 24.74 & 5336 & 2.14 \\
Behenic acid & 28.98 & 2163 & 0.87 \\
Unknown & 16.77 & 9559 & 3.83 \\
Unknown & 19.03 & 8015 & 3.21 \\
Unknown & 20.61 & 9276 & 3.72 \\
\hline
\end{tabular}




\section{Acknowledgements}

The authors are thankful to Md. Jamilur Rahman, S.O. and Md. Mosaraf Hossan, Jr. Tech. of Chemical Research Division, BCSIR Laboratories, Qudrat-i-Khuda road, Dhaka-1205, for their help.

\section{References}

1. R. N. Chopra., S. L. Nayar and I. C. Chopra, "Glossary of Indian Medicinal Plants", CSIR, New Delhi, 1956, p 177.

2. V. C. Chitravanshi, A. P. Singh, S. Ghosal, B. N. K. Prasad, V. Srivastave, and J. S. Tandon, Int. J. Pbarmacog., 1992, 30, 71.

3. P. G. Rao and J. Kodandaramaiah, Gopala Rao P. and J. Kodandaramaiah, Association of chlorophyll content, phyllotaxy, photosynthesis and $\mathrm{B}$ group vitamins in some $\mathrm{C}_{3}$ and $\mathrm{C}_{4}$ plants. Proc.Indian Acad. Sci. (Plant Sci.)., 1982, 91(6), 495-500.

4. "A Manual of Laboratories Techniques", National Inst. of Nutrition, Indian Council of Medical Research, Hydrabad-500007, India, 1976, p.1,2,3,35.

5. S. E. Allen, S. Grim and A. P. Rowland, "Chemical Analysis. Methods in Plant Ecology", 1986, p 51.

6. "British Standard Methods of the Analysis of Oils and Fats", B. S. 684. British Standards Institution Incorporated by Royal Charter, British Standards House, 2 Park ST, London, W.1., 1958.

7. G. Mowlah, N. M. Sheikh and A. S. M. Kamal, "A Hand Book on Edible Oils and Fats, With Special Reference to Bangladesh", (1st edition), City press, Dhaka-1000, Bangladesh, 1990, p 44.

8. R. C. Griftin, “A. M. S. M. Technical Method of Analysis”, (2nd edition), Mc Graw-Hill Co. Inc., New York and London, 1960, p 299.

9. A. K. Singh, Acta Botanical Hungarica, 1983, 29(1-4), 281-292.

(Received : 23 September 2009; accepted : 22 May 2011) 